$\xi=-1$

\title{
Corporate Social Responsibility and Financial Performance of Deposit Money Banks: A new Evidence from Nigeria
}

\author{
Oluyinka Isaiah Ogungbade * \\ ${ }^{1}$ Department of Accounting, Afe Bbabalola University Ado-Ekiti Km 8.5, Afe Babalola Way, P.M.B. 5454, Ado-Ekiti, Ekiti State, Nigeria \\ *Corresponding author E-mail: ogungbadeoi@abuad.edu.ng
}

\begin{abstract}
The primary purpose of every business firm is to make a profit which is the economic performance in the Triple Bottom Line. However, a social and environmental performance which is Corporate Social Responsibility (CSR) has been argued to be very crucial for firms' sustainability. This argument has drawn the attention of researchers across the globe to various empirical studies which have produced confounding results. This study provides new evidence from Nigeria by disaggregating CSR into Community Development, Education and Health, and finding their effect on performance which is proxied by Return on Assets. The data were extracted from the audited annual reports of 12 Deposit Money Banks listed on Nigeria Stock Exchange for ten years, 2009-2008. The study found out that CSR on Community Developments has a positive and significant effect on financial performance. On the contrary, the study reveals that CSR on Education has an insignificant positive effect on financial performance, and CSR on Health has a negligible negative effect. The study recommends that management of Deposit money banks in Nigeria should not blindly engage in CSR activities, but should selectively select the CSR activities that can take care of all the stakeholders' interest.
\end{abstract}

Keywords: Corporate Social Responsibility; Community Development; Educations; Financial Performance; Health

\section{Introduction}

Profit maximisation has always been the primary goal of every business firm, and it is the yardstick for measuring their performance. However, corporations have pursued profit maximisation at the expense of environmental protection and even labour rights and consumers' interest, which cause many negative externalities ( $\mathrm{Li}, 2018)$. This development has put pressure on business firms as the society does not evaluate their performance based on profitability alone but also based on their commitment to social responsibility obligations (Li, 2018). The growing interest in corporate social responsibility (CSR) has caused organisations to be utilising it as a public relations (PR) tool for corporate image change(Yoo \& Lee, 2018).

The concept of CSR was first introduced in the 1950s when some former scientists argued the social roles of large organisations (Xie \& Ward, 2019). The intensifying demand for stakeholders' interest in social performance has put pressure on firms to embark on CSR practices and reporting. Some corporations have quickly launched on CSR practices and are reporting them via their annual reports, placing the information on their websites or publishing a separate report regarding their CSR activities(Rajput, Batra, \& Pathak, 2012). From time to time, numerous governmental and non-governmental organisations worldwide are involved in many CSR initiatives costing billions of dollars(Sulphey, 2017). The conceptual support for CSR is that CSR practices would enhance firms' reputations in the consumers' sight and thereby lead to improved performance(Yang \& Stohl, 2020). One school of thought is that CSR could be adopted as a firm strategy to develop a competitive advantage over the competitors, which would increase profitability. On the contrary, another school of taught states that CSR is only a cost to the organisations, negatively affecting the firms' performance(Khurshid, Shaheer, Nazir, Waqas, \& Kashif, 2017).

The relationship between corporate social responsibility and financial performance has tremendously attracted researchers' attention, but empirical studies have produced mixed results(Galant \& Cadez, 2017). Some authors argue that a positive relationship exists between corporate social responsibility and financial performance (Fauzi \& Idris, 2009), while others argue otherwise. The host community of the company occupies a central place in organisational culture and determines the firms' performance in the long run(Nasieku, Togun, \& Olubunmi, 2014)

Extant studies suggest that large firms, because of their higher capital ratio and more female and minority directors, practice CSR more than the small firms (Cornett, Erhemjamts, \& Tehranian, 2014). Even though there have been many studies on the relationship between CSR and firms' performance, there is no consensus regarding the relationship's sign and size (Lv, Li, \& Mitra, 2020). Siddiq and Javed (2012) posit that some firms focus on community growth but ignores internal factors and argues that it is difficult to expect CSR from firms because CSR activities may not influence performance. Therefore, this study provided a new evidence on the relationship between CSR and performance. 


\section{Literature review}

This section comprises the conceptual clarifications, theoretical clarifications, and empirical review.

\subsection{Conceptual clarifications}

\subsubsection{Corporate social responsibility (CSR)}

Corporate Social Responsibility (CSR) refers to the firms 'social and environmental practices. "CSR is about treating key stakeholders responsibly"(Hopkins, 2014, p1). Various organisations, including Governmental and Non-Governmental Organisations (NGOs) and employers 'associations, regard CSR as a panacea to the global poverty gap, social exclusion, environmental degradation, and revitalise neighbourhood (Marrewijk, 2002). Hopkins (2014) argues that if the charity fails because a company fails, it is a disaster, and urge Government to take up CSR and look after the vulnerable groups as companies that practice CRS for too long may go out of business very soon. Also, CSR is a corporate engagement with society through which they rebrand their core values towards protecting the environments, eradicating poverty, creating employment and labour practices, education, and human development(Khan, Khan, Ahmed, \& Ali, 2012). Despite the CSR concept's popularity, it still lacks a universally accepted definition (Golrida, Subroto, Sutrisno, \& Saraswati, 2018; Mikolajek-Gocejna, 2016)

\subsubsection{Performance}

The primary goal of every business is to make a profit; hence, profitability is a major way of measuring the financial performance of business organisations, Performance consist of behavioural and outcome concept, it is multi-dimensional and dynamic comprising individual, situational and regulation perspectives (Sonnentag \& Frese, 2002). Firms' objective in the $21^{\text {st }}$ century is Continuous performance because it leads to development and progress. A well-performing firm is identified by its ability to generate high and long-term profits that will create employment opportunities and improve individuals' wealth (Taouab \& Issor, 2019).

\subsection{Theoretical review}

Triple Bottom Line and Stakeholders underpin this study. Theories, as explained below.

\subsubsection{Triple bottom line theory}

John Elkington developed the Triple Bottom line Theory in 1998 in his book entitled "Partnerships from cannibals with forks: The triple bottom line of 21st-century business"(Brin \& Nehme, 2019; Elkington, 1998). The theory states that long-term partnership is vital for companies making the transition to sustainability(Elkington, 1998). The theory consists of three dimensions of performance comprising economic, social, and environmental performance, which firms must pursue to achieve sustainability, which is the focus of 21 -century business(Brin \& Nehme, 2019). Many organisations, both public and private, profit-making, and Not-for-profit, have embraced the Triple Bottom Line Approach, otherwise known as corporate responsibility or Sustainability reporting(Colbert \& Kurucz, 2007).

The economic performance addresses the financial performance, which is the primary goal of a business firm. However, to achieve sustainable profitability in the long-run, social performance, which addresses workers' welfare and customer satisfaction and environmental performance regarding environmental protection and community development, is fundamental.

\subsubsection{Stakeholders theory}

According to Freeman (1984), a stakeholder is any group or individual who can affect or is affected by attaining the organisations's objectives. Stakeholders' theory is concerned with the relationship between an organisation and its stakeholders on meeting multiple stakeholders' expectations comprising customers, suppliers, employees, investors, and communities. (Freeman, Harrison, \& Zyglidopoulos, 2018).

Unlike the shareholders' theory that focuses on satisfying the investors' interest, the stakeholders' theory argues that corporations should create value for all investors or groups with a stake in them. The various stakeholders have a reciprocal interest because they affect each other in terms of harms and benefits, rights, and duties (Freeman, 2016). CSR states that a business firm should not only pursue profitability to satisfy investors and management at the expense of consumers, employees, and host communities. At the same time, the CSR discourages firms from using all the firms' resources on philanthropy at the detriments of the shareholders who are the real owners of the business.

\subsection{Empirical review}

The analysis of 3,481 unbalanced observations from the listed firms in China for seven years (2009-2015) via Generalised Method of moments reveals that Corporate Social Responsibility has a positive and significant relationship with performance. On the contrary, the study shows that earnings management negatively moderates the relationship between CSR and performance (Sial, Chunmei, Khan, \& Nguyen, 2018). Similarly, using panel corrected standards estimate errors to examine CSR's effect on firms' financial performance in South Africa, the study shows that CSR has a strong positive impact on financial performance (Nyeadi, Ibrahim, \& Sare, 2018). The authors argue further that some components of CSR, including governance performance, have a positive effect on financial performance, but social parts and environmental components do not have a relationship with firms' performance. However, they established a positive impact of CSR on the extractive industry's financial performance only; there was no evidence of the CSR effect on performance in the financial sector.

Likewise, in Turkey, Akben-Selcuk (2019) argues that a positively significant relationship exists between CSR and financial performance; however, ownership concentration negatively moderates the relationship between CSR and performance. The relationship between CSR and performance is complex, and the complexity is due to the inseparability between CSR and its environments, which hurts empirical studies; hence, the empirical results are highly contextual and lack generalisation (Golrida et al., 2018). The relationship between CSR and performance is multifaceted because of country characteristics and CSR forms and dimensions because country char- 
acteristics determine CSR practices' tendency, which finally determines the strength of the relationship between CSR and performance (Golrida et al., 2018).

CSR is desirable by companies because it reduces risks, increases brand values and transparency, and ultimately it has a positive effect on firms' financial performance(Gautam, Singh, \& Bhowmick, 2016). It started in India as an act of philanthropy but later became mandatory for companies. An investigation of CSR in the US reveals the extent to which firms will benefit from CSR activities depends on their reputations among stakeholders and ownership structure (Alshammari, 2015).

The regression analysis of the largest 500 Indian companies also reveals a statistically significant positive relationship between CSR and financial performance(Rajput et al., 2012). However, the sales revenue and profits that the authors used to proxy performance are questionable because the metrics did not measure performance in terms of the assets that generate them. The pressure for social responsibility on listed firms is more than for non -listed firms, and extant studies reveal that listed firms show responsible business practices and record better financial performance than non-listed firms (Mishra \& Suar, 2010).

Similarly, the analysis of 62 companies from3 industries in China revealed the CSR has a positive effect on financial performance, but its impact on market prediction was not certain (Xie \& Ward, 2019). Similarly, an unbalanced panel analysis of 4,500 firms for 19 years also reveals that CSR positively affects financial performance(Kang, Germann, \& Grewal, 2016). Another evidence from china reveals that firms that practice CSR perform better than firms that did not engage in CSR, and firms' age and sound corporate governance mechanisms also positively moderate the relationship(Chang, Chen, \& Min-Cheng, 2018).

In Nigeria, the multiple regression results of the primary data collected from 270 individuals in the host communities of international oil companies in the Niger Delta region indicate a positive and significant CSR effect on firms' performance (Daubry, 2020). CSR components comprising centrality, visibility, and voluntary contribution were used to proxy CSR, and relational capital and employees' commitment were used to proxy organisational performance.

Likewise, a study of CSR in 16 countries indicates that firms in coordinated market economies practice CSR more than firms in liberal market economies (Walker, Zhang, \& $\mathrm{Na}$ (Nina), 2019). Also, a significant and positive relationship exists between CSR and firms' performance in a coordinated market economy but not in a liberal market economy; and a negative relationship exists between corporate social irresponsibility and financial performance in a liberal market economy but not in a coordinated market economy (Walker et al., 2019).

However, using employee relations and environmental scores to proxy CSR, Moore (2019) argues that CSR hurts firms' financial performance. Similarly, Zajkowski and Domańska (2019) argue that some CSR activities positively affect financial performance and liquidity, while others negatively affect. In like manner, some authors posit that CSR has a positive effect on an environmentally sensitive industry's financial performance but has an adverse effect on financial performance in sectors that are not sensitive to their environment (Lin, Chang, \& Dang, 2015). Furthermore, existing studies reveal that CSR to some stakeholders will increase performance, but CSR to customers has a negative effect on financial performance(Khurshid et al., 2017).

Moreover, when CSR was disaggregated into health issues, transportations, and education in Nigeria, none of them had any significant effect on firms' financial performance for 22 years (1992-2014)(Tijani, Adeoye, \& Alaka, 2017). Evidence from India also suggests that no significant relationship exists between CSR and financial performance (ROA and ROE), which implies that CSR is not related to short-term oriented accounting performance(Kim \& Oh, 2019). Another evidence from Nigeria also suggests that CSR has an insignificant negative effect on financial performance proxied by profit after tax (Akinleye \& Faustina, 2017). Though, the study examined only five companies and for only five years. In this same manner, empirical evidence from Nepal shows that CSR has a significant negative relationship with Return on Asset but has an insignificant relationship with Return on Equity and Net Income(Wagle, 2020). However, the study examined only three banks out of 27 and covered four years.

The empirical findings' mixed results have been linked to measurement problems; solving the measurement problem would provide a clearer relationship(Yang \& Stohl, 2020). Given the confounding results from the existing empirical studies and the fact that many of them did not investigate CSR on Community Development, Health, and Education, coupled with various limitations in their methodologies, this study shall test the following hypotheses:

$\mathrm{H}_{01}$ : CSR on Community Development does not significantly affect the financial performance of Deposit Money Banks in Nigeria.

$\mathrm{H}_{02}$ : CSR on Education by the Deposit Money Banks in Nigeria does not significantly affect their financial performance.

Ho3: CSR on Health by the Deposit Money Banks in Nigeria does not significantly affect their financial performance.

\section{Methods}

The study collected data from all the 12 Deposit money banks listed on the Nigerian stock exchange for ten years, 2009-2018. The data were extracted from the audited annual reports of the banks. CSR was disaggregated into Education, Education, and Health, and Return on Assets measured financial performance. The study employed multiple linear regression, having carried out some diagnostic tests. One sample Kolmogorov test was employed for the normality test, while the study used Variance Inflation Factor and Durbin Watson for multicollinearity test and auto-correlation, respectively. Hausman's test was employed to select between fixed and random effect models, and the selections favored the random effect model. The study extracted CRS expenditures on community development, Education, and Health to measure CSR and used Return on Asset to proxy performance.

\section{Results}

The results comprise both descriptive and inferential analysis

\subsection{Descriptive analysis}

Table 1 provides information on CSR expenditures, which comprises community development, health, and education. 
Table 4.1: Descriptive Statistics

\begin{tabular}{|c|c|c|c|c|c|}
\hline & Community Development & Education & Health & Total CSR & ROA \\
\hline Mean & $9.58 \mathrm{E}+08$ & $3.06 \mathrm{E}+08$ & $6.02 \mathrm{E}+08$ & $1.88 \mathrm{E}+09$ & 0.0232 \\
\hline Median & 95701976 & 155546455 & 1000000 & $1.16 \mathrm{E}+08$ & 0.016113 \\
\hline Maximum & $9.32 \mathrm{E}+10$ & $1.71 \mathrm{E}+10$ & $6.86 \mathrm{E}+10$ & $1.73 \mathrm{E}+11$ & 0.264573 \\
\hline Std. Dev. & $8.50 \mathrm{E}+09$ & $1.87 \mathrm{E}+09$ & $6,26 \mathrm{E}+09$ & $1.59 \mathrm{E}+10$ & 0.041711 \\
\hline Skewness & 10.79936 & 7.885450 & 10.80862 & 10.63128 & 2.161971 \\
\hline Kurtosis & 117.7538 & 65.67959 & 117.8866 & 115.1881 & 13.74802 \\
\hline Jarque-Bera & 68174.74 & 20887.26 & 68331.20 & 65191.31 & 671.0822 \\
\hline Probability & 0.000000 & 0.000000 & 0.00000 & 0.000000 & 0.000000 \\
\hline Sum & $1.15 \mathrm{E}+11$ & $3.67 \mathrm{E}+10$ & 7.22E +10 & $2.26 \mathrm{E}+11$ & 2.795579 \\
\hline Sum sq Dev & 722.5917 & 4.17E+20 & $4.66 \mathrm{E}+21$ & $3.00 \mathrm{E}+22$ & 0.207036 \\
\hline Observation & 120 & 120 & 120 & 120 & 120 \\
\hline
\end{tabular}

Source: Author's Computation (2020).

The average amount spent on community development was $\$ 958 \mathrm{~m}$ per annum. The maximum amount spent was $93.2 \mathrm{~b}$ per annum, while the minimum amount spent on community development during the investigation period was $\$ 513,720$. The standard deviation of community development was $\$ 850 \mathrm{~m}$, and the data does not have a normal distribution, as shown by Jarque -Bera probability that is less than $5 \%$ (JB Statistics $=68174.74, \mathrm{P}=0.000000)$.

On education, the investigated banks spent $\$ 306 \mathrm{~m}$ on average, the maximum amount they spent was $\$ 17.1 \mathrm{~b}$, and the minimum amount was 0.000000 , which implies there were some years they did not spend any amount on education. The standard deviation from the mean was $18.7 \mathrm{~m}$, and the data were not normally distributed (JB Statistics $=20887.26, \mathrm{P}=0.000000<0.05$ ). Another area of corporate social responsibility which the investigated banks focused on was health. On average, a sum of $602 \mathrm{~m}$. The maximum amount spent on health was $\$ 68.6 \mathrm{~b}$, and the minimum amount was $\$ 0.000000$, which implies there were some years where no amount was spent on health. The standard deviation was $162.6 \mathrm{~m}$ and the data was not normally distributed (JB statistics $=68331.20, \mathrm{P}=$ $0.000000<0.05)$. The total amount spent on Corporate social responsibility was 18.8 on average; the maximum amount spent was $\$ 173 \mathrm{~b}$ while the minimum amount spent was 1427,000 . The standard deviation was $159 \mathrm{~m}$, and the data was not normally distributed $(\mathrm{JB}$ statistics $=65191.31, \mathrm{P}=0.000000<0.05)$.

Finally, the average return on the asset was 0.0232 , which is about $2 \%$, and the maximum performance was about $26.5 \%$ return on asset $(\mathrm{ROA}=0.264573)$ while the minimum performance was -0.09856 which implies $9.856 \%$ loss. The standard deviation was 671.0822 , and the data were not normally distributed $(\mathrm{JB}$ statistics $=671.0822, \mathrm{p}=0.000000)$.

\subsection{Diagnostic tests}

The study tested some assumptions of the classical linear regression model before proceeding to regression analysis. The hypotheses tested include normality tests, multicollinearity tests, and autocorrelation tests.

\subsubsection{Normality test}

The Jarque-Bera test in table 4.1 shows that the performance does not have a normal distribution. The study transformed the data to ensure its normality before proceeding to regression.

Table 2: One-Sample Kolmogorov-Smirnov Test

\begin{tabular}{lll}
\hline & & ROA \\
\hline $\mathrm{N}$ & & 109 \\
Normal Parameters ${ }^{\mathrm{a}, \mathrm{b}}$ & Mean & -1.7236 \\
& Std. Deviation & .39834 \\
Most Extreme Differences & Absolute & .048 \\
& Positive & .048 \\
& Negative & -.035 \\
Test Statistic & & .048 \\
Asymp. Sig. (2-tailed) & & $.200^{\text {c,d }}$ \\
\hline
\end{tabular}

Source: Author's Computation (2020).

The P-value of the One-sample Kolmogorov-Smirnov Test, which is greater than 5\% shows that deviation from normality is not significant $(\mathrm{P}=.200)$. This result implies that the data has a normal distribution.

\subsubsection{Multicollinearity test}

The study tested for multicollinearity to detect a strong or perfect correlation among the independent variables. The presence of multicollinearity can affect the regression output and lead to the wrong conclusion. The study used the Variance Inflation Factor (VIF) and Tolerance to detect the presence of multicollinearity.

Table 3: Variance Inflation Factor

\begin{tabular}{lll}
\hline & Collinearity Diagnostic & \\
\hline & Tolerance & VIF \\
Community Development & .513 & 1.950 \\
Education & .485 & 2.064 \\
Health & .515 & 1.950 \\
\hline
\end{tabular}

Community Development

Education

Collinearity Diagnostic

Dependent Variable: ROA

Source: Author's Computation (2020)

Table 3 shows that the VIF values of all the independent variables are greater than one and less than ten, which implies the absence of multicollinearity. In Like manner, Terrence values greater than 0 , but less than one shows no multicollinearity problem. 


\subsubsection{Autocorrelation test}

This study also tested for autocorrelation using Durbin-Watson.

Table 4: Auto Correlation Test

\begin{tabular}{lllll}
\hline Model & $\mathrm{R}$ & $\mathrm{R}$ Square & Adjusted R Square & Std. Error of the Estimate \\
\hline 1 & $.501^{\mathrm{a}}$ & .251 & .231 & .03671 \\
a. Predictors: (Constant) Communitydev, Education, Health & \\
b. Dependent Variable: ROA &
\end{tabular}

Source: Author's Computation (2020)

The Durbin -Watson result, which is 2.107 , falls within the acceptable region of $1.5-2.5$. This result indicates that there is no autocorrelation problem.

\subsection{Post estimation test}

The regression model can be estimated using the Pooled Ordinary Least square, Random effect model, and Fixed effect model. However, since the data is panel data, the study employed the Hausman test to select the appropriate model between the random and fixed-effect models. The study tested the following hypothesis:

$\mathrm{H}_{0}$ : Random effect model is appropriate

$\mathrm{H}_{\mathrm{a}:}$ Fixed effect model is appropriate.

The model of the study tested the effect of corporate social responsibility on performance. The CSR metrics include community development, Education, and Health, and performance was measured using ROA. Since the p-value of Hausman's test is 0.3629, which is greater than 0.05 , the null hypothesis is accepted, and the alternate hypothesis is rejected. Therefore, the model was estimated using the random effect model.

Table 5: Hausman Test

\begin{tabular}{llll}
\hline Model & Test Summary & Chi-Square Statistics & Chi-Square d.f \\
\hline 1 & Cross-section random & 3.192230 & 3 \\
\hline Source: Author's Computation (2020) & & & \\
\end{tabular}

\subsection{Hypotheses testing}

This section comprises the testing of hypotheses stated in chapter one of the study.

\subsubsection{Corporate social responsibility and financial performance}

The goodness of fit of this model is revealed by R-Square, which shows that about $15.2 \%$ of changes in Nigerian banks' financial performance were accounted for by the Social responsibilities of the banks during the period of investigation. Even though the R-square is very low, the F-probability value $($ F-Prob. $=0.023742<0.05)$ is significant, which means the model is valid. This outcome indicates that CSR has a significant effect on financial performance.

Table 6: Effect of CSR on Financial Performance

\begin{tabular}{lllllll}
\hline Variable & Coefficient & Std. Error & t-Statistic & Prob. & R-Square & F-Statistics \\
C & -3.349378 & 0.655105 & -5.112737 & 0.0000 & 0.151752 & 3.399107 \\
CDLN & 0.121544 & 0.043123 & 2.818557 & 0.0066 & & \\
EducationLN & 0.012180 & 0.038062 & 0.320006 & 0.7501 & & \\
HEALTHLN & -0.053684 & 0.028626 & -1.875335 & 0.0659 & & \\
\hline
\end{tabular}

Source: Author's Computation (2020).

Table 6 shows that community development has a significant positive effect on the banks' financial performance during the investigation $(\mathrm{B}=0.121544, \mathrm{P}=0.0066)$. Therefore, Hypothesis 1 of the study states that "CSR on Community Development does not significantly affect the financial performance of Deposit Money Banks in Nigeria" is rejected. Similarly, CSR on education has an insignificant positive effect on Nigerian banks' financial performance during the investigation $(B=0.012180, p=0.7501>0.05)$. Therefore, hypothesis 2 of the study states that "CSR on Education by the Deposit Money Banks in Nigeria does not significantly affect their financial performance," cannot be rejected. However, CSR on health has a negative but insignificant effect on financial performance $(\mathrm{B}=-0.053684, \mathrm{p}-$ value $=0.0659$ ). Therefore, hypothesis 3 of this study, which posits that "CSR on Health by the Deposit Money Banks in Nigeria does not significantly affect their financial performance," cannot be rejected.

\section{Discussion}

This study established a significant positive effect of CSR on community development on financial performance. This result implies that the host communities where Deposit money banks in Nigeria are located considerably cherish the banks' CSR supports over the years and are paying back in terms of high patronage or whatever means to support the banks. This result contradicts some previous studies in Nigeria (Tijani et al., 2017) and India (Kim \& Oh, 2019). However, it supports some studies in China (Chang et al., 2018; Kang et al., 2016) and Nigeria (Daubry, 2020).

The study also shows that CSR on education has an insignificant positive effect on financial performance, while CSR on health has a negligible negative impact on financial performance. The insignificant positive effect of CSR on performance is supported by previous studies in Nigeria (Tijani et al., 2017) and India (Kim \& Oh, 2019). The insignificant negative effect also supports previous studies in Nigeria (Akinleye \& Faustina, 2017) and Nepal (Wagle, 2020). Even though CSR's positive impact on performance was not statistically significant, it supports some of the other existing studies that also found positive effects (Akben-Selcuk, 2019; Nyeadi et al., 2018; 
Sial et al., 2018). Similarly, the negative effect of CSR on financial performance is supported by other previous findings (Khurshid et al., 2017; Lin et al., 2015; Moore, 2019; Zajkowski \& Domańska, 2019).

This result implies that CSR expenditure on Community Development can lead to improved financial performance, but the effect of CRS expenditure on Education and Health lacks statistical evidence. Despite the lack of statistically significant effect of CSR Education and Health on performance, the result indicates that continuous spending on education as a CSR project may improve performance, while CSR on health may reduce financial performance.

\section{Conclusion}

This study examined the effect of CSR on the financial performance of deposit money banks in Nigeria. Specifically, the study examined the impact of CSR on Community development, Education, and Health on Financial performance. The results indicate that CSR on community development considerably improves financial performance, but the effect of CSR Education and Health could not be statistically established. The study recommended that deposit money banks in Nigeria continue to engage in CSR activities on community development because it will improve their performance. This recommendation lends credence to the Triple Bottom Lines theory that firms should pursue social and environmental performance along with the financial performance to achieve sustainability.

However, firms should take caution on CSR activities on education and health as the activities may not create value for the firms. This result is in line with stakeholders' theory that the interests of all the stakeholders should be taken into consideration while pursuing firms' objectives. Future researchers may consider investigating other components of CSR activities that this study did not capture for lack of data availability.

\section{References}

[1] Akben-Selcuk, E. (2019). Corporate social responsibility and financial performance: The moderating role of ownership concentration in Turkey. Sustainability (Switzerland), 11(13), 1.10. https://doi.org/10.3390/su11133643.

[2] Akinleye, G. T., \& Faustina, A. T. (2017). Impact of Corporate Social Responsibility on the Profitability of Multinational Companies in Nigeria. Global Journal of Management and Business Research: D Accounting and Auditing, 17(3), 27-35.

[3] Alshammari, M. (2015). Corporate Social Responsibility and Firm Performance: The Moderating Role of Reputation and Institutional Investors. International Journal of Business and Management, 10(6), 15-28. https://doi.org/10.5539/ijbm.v10n6p15.

[4] Brin, P., \& Nehme, M. N. (2019). Corporate Social Responsibility: Analysis of Theories and Models. EUREKA: Social and Humanities, 5(5), 2230. https://doi.org/10.21303/2504-5571.2019.001007.

[5] Chang, Y., Chen, T.-H., \& Min-Cheng, S. (2018). Corporate Social Responsibility, Corporate Performance, and Pay-Performance SensitivityEvidence from Shanghai Stock Exchange Social Responsibility Index. Emerging Markets, Finance \& Trade; Abingdon, 54(5), 1183-1203. https://doi.org/10.1080/1540496X.2016.1273768.

[6] Colbert, B. a, \& Kurucz, E. C. (2007). Three Conceptions of Triple Bottom Line Business Sustainability and the Role for HRM. Human Resource Planning, 30(1), 21-29. Retrieved from http://search.ebscohost.com/login.aspx?direct=true\&db=bth\&AN=24669027\&site=ehost-live

[7] Cornett, M. M., Erhemjamts, O., \& Tehranian, H. (2014). Corporate Social Responsibility and Its Impact on Financial Performance: Investigation of the U.S. Commercial Banks. SSRN Electronic Journal, 39. https://doi.org/10.2139/ssrn.2333878.

[8] Daubry, P. M. (2020). Corporate Social Responsibility and Organizational Performance of Oil Companies in Southern Nigeria. Walden University.

[9] Elkington, J. (1998). Partnerships from cannibals with forks: The triple bottom line of 21st-century business. Environmental Quality Management, 8(1), 37-51. Retrieved from https://search.proquest.com/ https://doi.org/10.1002/tqem.3310080106.

[10] Fauzi, H., \& Idris, K. M. (2009). The Relationship of CSR and Financial Performance: New Evidence from Indonesian Companies. Issues In Social And Environmental Accounting, 3(1), 66. https://doi.org/10.22164/isea.v3i1.38.

[11] Freeman, R., Harrison, J., \& Zyglidopoulos, S. (2018). Stakeholder Theory: Concepts and Strategies (Elements in Organization Theory). https://doi.org/10.1017/9781108539500.

[12] Freeman, R.E. (1984). Strategic management: A stakeholder approach. Boston: Pitman Publishing Inc.

[13] Freeman, R Edward. (2016). A Stakeholder Theory of the Modern Corporation. The Corporation and Its Stakeholders, pp. 38-48. https://doi.org/10.3138/9781442673496-009.

[14] Galant, A., \& Cadez, S. (2017). Corporate social responsibility and financial performance relationship: A review of measurement approaches. Economic Research-Ekonomska Istrazivanja , 30(1), 676-693. https://doi.org/10.1080/1331677X.2017.1313122.

[15] Gautam, R., Singh, A., \& Bhowmick, D. (2016). Demystifying relationship between Corporate Social Responsibility (CSR) and financial performance: An Indian business perspective. Independent Journal of Management \& Production, 7(4), 1034-1062. https://doi.org/10.14807/ijmp.v7i4.443.

[16] Golrida, K. P., Subroto, B., Sutrisno, T., \& Saraswati, E. (2018). The Complexity of Relationship between Corporate Social Responsibility (CSR) and Financial Performance. EMAJ: Emerging Markets Journal, 8(2), 19-25. https://doi.org/10.5195/emaj.2018.155.

[17] Hopkins, M. (2014). What is CSR all about? ASPIRARE, l(September), 1-21. Retrieved from https://www.researchgate.net/publication/272832575_What_is_CSR_all_about

[18] Kang, C., Germann, F., \& Grewal, R. (2016). Washing Away Your Sins? Corporate Social Responsibility, Corporate Social Irresponsibility, and Firm Performance. ... Journal of Marketing; Chicago, 80(2), 59. https://doi.org/10.1509/jm.15.0324.

[19] Khan, M. T., Khan, N. A., Ahmed, S., \& Ali, M. (2012). Corporate Social Responsibility ( CSR ) - Definition, Concepts and Scope ( A Review ). Universal Journal of Management and Social Sciences, 2(7), 41-52.

[20] Khurshid, M. K., Shaheer, H., Nazir, N., Waqas, M., \& Kashif, M. (2017). Impact of Corporate Social Responsibility on Financial Performance: The Role of Intellectual Capital. City University Research Journal, 247-263.

[21] Kim, W. S., \& Oh, S. (2019). Corporate social responsibility , business groups and financial performance : a study of listed Indian firms. Economic Research-Ekonomska Istraživanja, 32(1), 1777-1793. https://doi.org/10.1080/1331677X.2019.1637764.

[22] Li, Y. (2018). The Impact of Corporate Social Responsibility on Corporate Performance - Evidence From Listed Companies in the Sports Industry in China. 7(4), 107-121. https://doi.org/10.5430/afr.v7n4p107.

[23] Lin, C., Chang, R., \& Dang, V. T. (2015). An Integrated Model to Explain How Corporate Social Responsibility Affects Corporate Financial Performance. Sustainability, 7, 8292-8311. https://doi.org/10.3390/su7078292.

[24] Lv, P., Li, Y., \& Mitra, D. (2020). CSR and performance of family businesses: A systematic review. Australasian Accounting, Business and Finance Journal, 14(3), 75-85. https://doi.org/10.14453/aabfj.v14i3.6.

[25] Marrewijk, M. van. (2002). Concepts and Definitions of CSR and Corporate Sustainability - between agency and communion -. Entomologia Experimentalis et Applicata, 103(3), 239-248. https://doi.org/10.1023/A

[26] MIKOŁAJEK-GOCEJNA, M. (2016). The relationship between corporate social responsibility and corporate financial performance: Evidence from empirical studies. Comparative Economic Research, 19(4), 66-84. https://doi.org/10.1515/cer-2016-0030. 
[27] Mishra, S., \& Suar, D. (2010). Does corporate social responsibility influence firm performance of Indian companies? Journal of Business Ethics, 95(4), 571-601. https://doi.org/10.1007/s10551-010-0441-1.

[28] Moore, M. (2019). CSR \& Company Financial Performance. Western University. https://doi.org/10.2139/ssrn.3377842.

[29] Nasieku, T., Togun, O. R., \& Olubunmi, E. M. (2014). Corporate Social Responsibility and Organizational Performance: A Theoretical Review. International Journal of Humanities Social Sciences and Education (IJHSSE) Volume, 1(12), 106-114.

[30] Nyeadi, J. D., Ibrahim, M., \& Sare, Y. A. (2018). Corporate social responsibility and financial performance nexus: Empirical evidence from South African listed firms. Journal of Global Responsibility, 9(3), 301-328. https://doi.org/10.1108/JGR-01-2018-0004.

[31] Rajput, N., Batra, G., \& Pathak, R. (2012). Linking CSR and financial performance: An empirical validation. Problems and Perspectives in Management, 10(2), 42-49.

[32] Sial, M. S., Chunmei, Z., Khan, T., \& Nguyen, V. K. (2018). Corporate social responsibility, firm performance and the moderating effect of earnings management in Chinese firms. Asia-Pacific Journal of Business Administration, 10(2/3), 184-199. Retrieved from https://doi.org/10.1108/APJBA-03-2018-0051.

[33] Siddiq, S., \& Javed, S. (2012). The Impact of CSR on Organizational Performance. European Journal of Business and Management, 9(27), 40-46.

[34] Sonnentag, S., \& Frese, M. (2002). Performance Concepts and Performance Theory. In S. Sonnentag (Ed.), Psycological Management of Individual Performance (p. 26). https://doi.org/10.1002/0470013419.ch1.

[35] Sulphey, M. M. (2017). Corporate Social Responsibility or Corporate Social Irresponsibility: where should be the focus?. Problems and Perspectives in Management, 15(4), 293-301. https://doi.org/293-301. https://doi.org/10.21511/ppm.15(4-1).2017.13.

[36] Taouab, O., \& Issor, Z. (2019). Firm Performance: Definition and Measurement Models. European Scientific Journal, 15(1), 93-106. https://doi.org/10.19044/esj.2019.v15n1p93.

[37] Tijani, A. A., Adeoye, A. O., \& Alaka, N. S. (2017). Effects of Corporate Social Responsibility on Banks Financial Performance in Nigeria: A Study of United Bank of Africa. International Journal of Business Economics and Management, 4(6), 136-147. https://doi.org/10.18488/journal.62.2017.46.136.147.

[38] Wagle, S. (2020). Corporate Social Responsibility on Firms' Financial Performance: Evidence of Banking Sectors of Nepal. Journal of Balkumari College, 9(1), 89-94. https://doi.org/10.3126/jbkc.v9i1.30091.

[39] Walker, K., Zhang, Z., \& Na (Nina), N. (2019). The Mirror Effect: Corporate Social Responsibility, Corporate Social Irresponsibility and Firm Performance in Coordinated Market Economies and Liberal Market Economies. British Journal of Management, 30(1), 151-168. https://doi.org/10.1111/1467-8551.12271.

[40] Xie, X., \& Ward, P. (2019). The Impact of Corporate Social Responsibilities on Financial Performance in China. Duke.

[41] Yang, Y., \& Stohl, C. (2020). The (in)congruence of measures of corporate social responsibility performance and stakeholder measures of corporate social responsibility reputation. Corporate Social - Responsibility and Environmental Management, 27(2), 969-981. https://doi.org/10.1002/csr.1859.

[42] Yoo, D., \& Lee, J. (2018). The Effects of Corporate Social Responsibility ( CSR ) Fit and CSR Consistency on Company Evaluation : The Role of CSR Support. Journal of Sustainability, 10(2956), 1-16. https://doi.org/10.3390/su10082956.

[43] Zajkowski, R., \& Domańska, A. (2019). The Directions of Interrelations Between the Company 's Performance and Corporate Social Responsibility ( CSR ) Activities. Folia Oeconomica, 4(343), 211-234. https://doi.org/10.18778/0208-6018.343.13. 